\title{
INNOVATION OF SCHOOL INFORMATION SYSTEM BY MEANS OF WIFI
}

\section{Jindřich DANĚK}

Abstract: Article focuses on a question of the enlistment of new wireless technologies into school information system. New wireless technologies are faster and of better quality and therefore they can substitute a metallic net. In school information system they can represent an important role both in educational process and in principalship.

Key words: information system, school information system, wirelless technologies, WiFi.

\section{INOVACE ŠKOLNÍHO INFORMAČNÍHO SYSTÉMU PROSTŘEDNICTVÍM WIFI}

Resumé: Příspěvek se zabývá možností zařazení nových bezdrátových technologii do školního informačního systému. Nové bezdrátové technologie svou rychlostí a kvalitou mohou nahradit metalické sitě. Ve školním informačním systému mohou zastávat důležitou roli jak ve vzdělávacím procesu, tak v rízeni školy.

Kličová slova: informačni systém, školní informační systém, bezdrátové technologie.

\section{1 Úvod}

Informační a komunikační technologie (ICT) svými možnostmi zvyšují efektivitu práce a prosperitu ve všech oblastech lidské činnosti, tedy i ve vzdělávání. Stávají se pevnou součástí nejrůznějších informačních systému, $v$ našem případě především informačních systémů škol. Je potřeba si klást otázky, zda informační systémy školy ovlivňují nejen fungování škol jako institucí, ale jakým způsobem zasahují do vlastního průběhu edukačního procesu. Abychom si mohli uspokojivě na tuto otázku odpovědět, je nejprve nutné informační systém a informační systém školy charakterizovat.

\section{Charakteristika informačního systému}

Informační systém (IS) má za úkol shromažd'ovat, ukládat, zpracovávat, vytvářet a prijímat informace $\mathrm{z}$ okolního prostředí a vysílat informace do okolí IS. IS by měl tyto operace provádět bud' automaticky nebo podle požadavku uživatelů provádět operace jako je napríklad analýza informací, kontrola, koordinace, ale také komunikace či virtualizace (Suchánek, 2007, s. 4). Zpracování dat probíhá ve třech fázích, které jsou do jisté míry podobné vzdělávacímu procesu.

- vstup dat do IS

- zpracování informací

- výstup dat z IS

IS lze tedy definovat jako soubor lidí, technických prostředků a metod zajišt’ující sběr, přenos, uchování a zpracování dat za účelem tvorby prezentace informací pro potřeby uživatelů činných v systémech řízení. Za IS lze považovat jakékoliv seskupení lidí a informačních a komunikačních technologií (ICT). V dnešní době jsou IS založeny právě na využívání výpočetní techniky, která se tak stává základním prvkem IS (Suchánek, 2007, s. $4)$.

\section{3 Školní informační systém}

Školní informační systémy představují specifickou oblast využití informačních systému. Každý školní informační systém se skládá z jednotlivých prvků, kterými mohou být jednotliví učitelé, žáci, ředitel, rodiče, zřizovatelé škol atd. Mezi těmito prvky se uskutečňuje výměna informací a v návaznosti na tom probíhá i veškeré rozhodování a řízení. Pro počítačově podporované informační systémy je charakteristické, že výměna informací probíhá velmi rychle (např. učitel muže prostřednictvím svého počítače během několika okamžiku nahlédnout do klasifikace jakéhokoliv žáka (Dostál, 2007, s. 541). Aby mohly být provedeny výše uvedené operace, musí být $\mathrm{k}$ dispozici technologie, které nám zajistí rychlý a kvalitní přenos informací, dat, atd.

IS školy plní dvě hlavní funkce - řídící a pedagogickou. Nejzávažnější funkcí, kterou IS školy plní, jsou funkce pedagogické. Tyto funkce slouží $\mathrm{k}$ informační podpoře pedagogické činnosti na úrovni školy. Jsou zdrojem potřebných informací při hodnocení výchovně - 
vzdělávacího procesu, pomáhají učiteli s př́ipravou a vedením výuky, zajišt'ují obecné programy a zdroje informací. Pedagogické funkce, které plní IS školy, jsou převážně směřovány $\mathrm{k}$ žákovi. IS školy umožňuje využívat ICT $\mathrm{z}$ různých didaktických hledisek: mohou být nosičem obsahu učiva, extenzí, jako pracovní nástroj, testovací nástroj, kulisa a doplněk. Využitím ICT ve výuce (Kapounová, Pavlíček 2003; Dostál 2007; Burgnerová, 2001) se motivace žáka zvyšuje, jejich nasazení do výuky má však své negativa i pozitiva (Kropáč a kol., 2004). Je také umožněno podporovat další výuku žáka, využívat dalších možností ICT, jako např́ílad e-learning (Kolibač 2003). Cílem automatizovaných pedagogických systémů je také přenést běžnou agendu školy na osobní počítač a usnadnit tak práci učitelům, ředitelům a hospodárným pracovníkům.

Díky zvyšujícímu se významu ICT se také zvyšují nároky na poskytování kvalitních služeb ve vzdělávacích institucích. A to nejen uvnitř institucí, ale i ve vztahu k „zákazníkům“ žákům, studentům, rodičům, partnerům školy a zřizovatelům ( $\mathrm{k}$ tomu, aby informační systém fungoval, nejsou ICT nutné, jeho zavedením se však celý systém podstatně zefektivnil, prvky systému jsou lépe a rychleji dostupné).

Nutné je také odpovídajícím způsobem zrychlit vzájemnou komunikaci ICT - vytvořit kvalitní a dostatečně rychlou počítačovou sít', na kterou jsou $\mathrm{V}$ současné době multimedií kladený vysoké nároky. Díky bezdrátovým technologiím lze v současné takovou kvalitní sít vytvořit $\mathrm{s}$ nízkými pořizovacími náklady. Technologie, která obě kritéria (cena a rychlost komunikace) umožňuje, je WiFi.

\section{$4 \mathrm{WiFi}$}

Je jedna $\mathrm{z}$ bezdrátových technologií, která prodělala v poslední době velký vývoj. WiFi je zajímavá technologie, která se objevila rychle a neočekávaně. Rychle se vyvíjela, což je dáno nenákladností a naplněním běžných potřeb uživatele.

Signál se přenáší elektromagnetickým vlněním, které nahrazuje metalické kabely. Elektromagnetické vlny se liší vlnovou délkou a frekvencí a jsou široce užívaným přenosovým médiem. Chceme-li od sebe oddělit jednotlivé přenosové linky, musíme pro každou z nich použít jinou frekvenci. Volných frekvencí je však jen málo, a tak na bezdrátové sítě zbyly nelicencované frekvence $2,4 \mathrm{GHz}$ a $5 \mathrm{GHz}$. Provoz v obou pásmech je však regulován
Českým telekomunikačním úřadem (Horák. 2008, s. 52).

Vývoj bezdrátových sítí probíhal podobně jako u metalických sítí. Nejdříve živelně, posléze bylo nutné přijmout normu, která zajistí vzájemnou spolupráci sítí. Hlavní výrobci bezdrátové technologie tak založili alianci WECA (Wireless Ethernet Kompatibility Aliance - sdružení pro kompatibilitu bezdrátového Ethernetu), která stanovila požadavky na zařízení a zajistila tak vzájemnou kompatibilitu s výrobky ostatních výrobců. Při splnění těchto podmínek obdrží výrobek certifikát WiFi, který potvrzuje kompatibilitu s výrobky ostatních výrobců. Samotná wireless norma byla odvozena od Ethernetu, proto s ním má některé podobné znaky - př́stupovou metodu CSMA/CD a podobné složení paketu. Pro bezdrátové sítě LAN existuje několik standardů (Horák. 2008, s. 52).

V současnosti jsou povoleny a k dispozici následující standardy: $802.11 \mathrm{~b}, 802.11 \mathrm{~g}, 802.11 \mathrm{a}$, $802.11 \mathrm{n}$. Standardem $802.11 \mathrm{~b}$ se podrobněji zabývali Milan Klement a Jan Lavrinčík ve článku Bezdrátové sítě uveřejněné ve sborníku príspěvků konference Infotech 2007, proto se soustředíme především na novější standardy. Každý zjednotlivých standardů se vyznačuje vlastním specifikem. Standard $802.11 \mathrm{~g}$ využívá tak jako standard $802.11 \mathrm{~b}$ pásmo $2,4 \mathrm{GHz}$. Ovšem zásadním rozdílem je přenosová rychlost. Zatímco $802.11 \mathrm{~b}$ nabízí rychlost $11 \mathrm{Mb} / \mathrm{s}$, standard 802.11g nabízí přenosovou rychlost až $54 \mathrm{Mb} / \mathrm{s}$. Standard 802.11a využívá pásmo $5 \mathrm{Ghz}$, které nám minimalizuje rušení řadou zařízení pracujících ve frekvenci 2,4 Ghz (mikrovlnné trouby, otvírače garážových dveří, atd.). Výrobci WiFi zařizení se také domluvili na vzájemné zpětné kompatibilitě jednotlivých zařízení. Posledním standardem, který byl schválen $\mathrm{v}$ roce 2009, je 802.11n. Tento standard využívá současně pásmo $2,4 \mathrm{GHz}$ a $5 \mathrm{GHz}$. Dosahuje tak rychlostí vyšších než $100 \mathrm{Mb} / \mathrm{s}$.

Při rychlostech $54 \mathrm{Mb} / \mathrm{s}$, respektive $100 \mathrm{MB} / \mathrm{s}$ a více, lze velmi pohodlně a efektivně využívat všech služeb, které ICT ve školách umožňují. Je zajišsěn dostatečně kvalitní datový tok, který je potřebný pro řadu služeb, např. přehrávání videa, hlasové služby, internetové služby a mnoho dalších, které se uplatňují v edukačním procesu.

Vybudování bezdrátové sítě ve školním informačním systému má několik výhod oproti pevným metalickým sítím. První a zároveň nejdůležitější výhodou je finanční náročnost. Při budování bezdrátové sítě jsou náklady 
několikanásobně menší, než je to u pevných metalických či optických sítí. Náklady na vybudování bezdrátové sítě čítající 16 PC včetně řídícího PC se pohybují kolem částky 10000,- Kč (bezdrátové karty, wifi router, anténa), náklady na vybudování stejné sítě pomocí metalických kabelů se pohybují kolem částky 50000,- Kč (kabely, switch, server).

Druhou výhodou, je pokrytí signálem, kdy je zajištěno neomezené využití WiFi na všech místech vně i mimo budovy školy a tedy její efektivní využívání. Odpadá tak nutnost fixace počítače na jediné místo $\mathrm{v}$ budově. $\mathrm{U}$ všech bezdrátových technologií, nejenom WiFi, je však nutné, aby počítače a jejich periferie umožňovaly bezdrátové technologie využívat, obsahovaly tedy kartu pro bezdrátový př́stup $\mathrm{k}$ síti. V současnosti tento problém odpadá, naprostá většina počítačů, notebooku, tiskáren a další tyto karty obsahují a bezdrátová komunikace je plně zabezpečena a podporována.

\section{Závěr}

WiFi se dostává díky svým novým standardům do popředí zájmu. Nové standardy jsou stále více využívány ve veřejném sektoru a je jen otázka času, kdy se plnohodnotně uplatní jako fyzická a linková vrstva školních informačních systémů. Jak již bylo řečeno, velmi důležitá je však také ekonomická stránka věci. WiFi tak mohou ušetřit značnou část finančního rozpočtu školy. Díky rychlému vývoji bezdrátových sítí lze v budoucnosti očekávat jejich stále častější využívání v edukačním procesu, jak ze stran pracovníků zajišt'ující edukační proces, tak ze strany zákazníků (žáků, rodičů).

\section{Literatura}

[1] DOSTÁL, J. Školni informační systémy. In Infotech 2007. Sborník príspěvki̊ z konference s mezinárodní účastí konané 11. 9. 2007

v Olomouci. Olomouc: Votobia Olomouc, 2007, s. 540-547. ISBN 978-80-7220-301-7.

[2] HAROLD, D. Bezdrátové sitě Wi-Fi. 1. vyd. Praha: Grada, 2006. 336 s. ISBN 80-247-1421-3.

[3] HORÁK, J., KERŠLÁGER, M. Počitačové sitě prozačínající správce. 4. vyd. Brno: Computer Press, 2008. 328 s. ISBN 978-80-2512073-6.

[4] KAPOUNOVÁ, J., PAVLÍČEK J. Počitače ve výuce a učení. 1. Vyd. Ostrava: Ostravská univertita, 2003. ISBN 80-7042-265-3.

[5] KLEMENT, M., LAVRINČÍK, J. Bezdrátové sitě. In Infotech 2007. Sborník prisspěvkì z konference s mezinárodní účastí konané 11.9. 2007 v Olomouci. Olomouc: Votobia Olomouc, 2007, s. 579-582. ISBN 978-80-7220-301-7.

[6] KOLIBAČ, R. eLearning - moderní forma vzdělávání. 1. vyd. Ostrava: Ostravská univerzita, 2003. ISBN 80-7042-970-4.

[7] STRÁNSKÝ, P. Wi-Fi 802.11n: průlom nebo propadák? [on-line]. 19.8.2008. [cit. 10. 11. 2009]. Dostupné na World Wide Web $<\mathrm{http}: / /$ www.svethardware.cz/art doc-

FAD274B53E574F67C12574B0004D5305.html $>$.

[8] SUCHÁNEK, P. Informační system vysoké školy jako součást projektu virtuální univerzity. 1.vyd. Karviná: SU OPF Karviná, 2003. ISBN 80-248-0260-0.

\author{
Mgr. Jindřich Daněk \\ Katedra technické a informační výchovy \\ Pedagogická fakulta UP \\ Žižkovo nám. č. 5 \\ 771 40, Olomouc, ČR \\ Tel: +420 585635819 \\ E-mail: danek4@post.cz \\ Www pracoviště: www.kteiv.upol.cz
}

